Jurnal Media Komunikasi Pendidikan Pancasila dan Kewarganegaraan

Volume 2, Nomor 1 April 2020

\title{
STATE RESPONSIBILITY DARI ADANYA SPACE DEBRIS LUAR ANGKASA
}

\author{
Devi Yusvitasari \\ Jurusan Hukum dan Kewarganegaraan \\ Fakultas Hukum dan Ilmu Sosial Universitas Pendidikan Ganesha Bali \\ E-mail: deviyusvitasari3@gmail.com
}

\begin{abstract}
Abstrak
Keberadaan benda-benda angkasa di ruang angkasa semakin meningkat. Negaranegara peluncur berlomba-lomba mendominasi ruang angkasa dengan meluncurkan benda-benda tersebut ke ruang angkasa. Padahal, benda-benda tersebut dapat menimbulkan kerusakan dan kerugian di muka bumi apabila tidak lagi berfungsi dan berubah menjadi sampah angkasa. Sampah angkasa itu pula dapat menyebabkan kerusakan pada benda angkasa lainnya yang masih berfungsi dengan baik di ruang angkasa. Sampah angkasa dan benda angkasa merupakan dua hal yang menjadi tanggung jawab negara peluncur, dan apabila menyebabkan kerusakan di ruang angkasa, suatu negara penuntut dapat menuntut ganti rugi terhadap negara peluncur. Oleh karena itu, artikel ini akan membahas mengenai sampah angkasa yang menabrak benda angkasa di ruang angkasa yang dalam hukum angkasa, peristiwa tersebut dianggap melanggar prinsip tanggung jawab atas dasar kesalahan apabila sampah angkasa tersebut terbukti menyebabkan kerusakan dan dibutuhkan suatu pengaturan hukum internasional yang mengatur mengenai masalah-masalahhukum angkasa, salah satu peraturan hukum angkasa tersebut yaitu Liability Convention 1972 yang mengatur pertanggungjawaban negara peluncur atas kerugian atau kerusakan yang di timbulkan benda antariksa. Sehingga komersialisasi ruang angkasa pada dewasa ini telah membawa kita kepada sebuah era baru dikegiatan keruangangkasaan. Indikator dari hal ini adalah meningkatnya jumlah benda ruang angkasa yang ditempatkan diruang angkasa. Atas hal tersebut kemungkinan timbulnya kerugian atau dampak negatif dari benda antariksa juga akan semakin besar. Oleh karena itu kami.
\end{abstract}

Kata Kunci: prinsip tanggung jawab, benda angkasa, negara peluncur, negara penuntut, sampah angkasa.

\begin{abstract}
The existence of celestial bodies in space is increasing. Launching countries are competing to dominate space by launching these objects into space. In fact, these objects can cause damage and loss on earth if they no longer function and turn into space junk. Space debris can also cause damage to other celestial bodies that still function well in space. Space trash and celestial bodies are two things that are the responsibility of the launching state, and if it causes damage in space, a claimant country can claim compensation for the launching state. Therefore, this article will discuss about space trash crashing into space objects in space which in space law is considered to violate the principle of responsibility on the basis of error if the space junk is proven to cause damage and an international legal regulation is needed
\end{abstract}


Jurnal Media Komunikasi Pendidikan Pancasila dan Kewarganegaraan

Volume 2, Nomor 1 April 2020

regarding the problem space law, one of the space law regulations is the 1972 Liability Convention which regulates the launching country's responsibility for loss or damage caused by space objects. So that the commercialization of space today has brought us to a new era in space activities. An indicator of this is the increase in the number of space objects placed in space. For this reason the possibility of loss or negative impact of space objects will also be even greater. Therefore we are.

Keywords: principle of responsibility, celestial body, launching state, space trash.

\section{Pendahuluan}

\section{Latar Belakang}

Pada dasarnya, peluncuran benda angkasa merupakan bentuk kemajuan teknologi dalam memanfaatkan ruang angkasa, yang memberikan dampak positif bagi kualitas kehidupan manusia. Kemajuan tersebut dapat dilihat dari peningkatan kualitas dan taraf hidup manusia, adanya berbagai penelitian di berbagai bidang ilmu pengetahuan, dan pencarian sumber-sumber alam baru dengan menggunakan berbagai jenis benda-benda angkasa. Dampak positif yang dapat dirasakan ialah terbukanya kesempatan bagi negaranegara lain yang ingin memajukan kemampuan negaranya di bidang ilmu pengetahuan dan teknologi ruang angkasa. Misalnya, dengan berkembangnya teknologi dan ditemukannya produk ilmu pengetahuan dan teknologi ruang angkasa, yaitu remote sensing2, atau penginderaan jauh yang berfungsi untuk pengelolaan sumber alam, untuk pembinaan lingkungan hidup, untuk peningkatan produksi pangan seperti pertanian, perkebunan, dan perikanan, serta perencanaan pemukiman dan tata guna tanah, pemetaan dan lain-lain Namun, hal tersebut juga menyebutkan bahwa aktivitas pemanfaat ruang angkasa guna peningkatan kualitas hidup manusia juga dapat menimbulkan berbagai kerugian baik di darat, ruang udara, dan di ruang angkasa itu sendiri. Kerugian merupakan dampak negatif yang bisa dirasakan oleh umat manusia akibat persaingan kedua negara adidaya tersebut, termasuk pula akibat keikutsertaan negara lain dalam memanfaatkan ruang angkasa. Kerugian tersebut dirasakan pada saat diciptakannya satelit mata-mata untuk kegiatan militer yang dapat membahayakan keamanan serta stabilitas nasional dari negara yang dimata-matai. Beberapa satelit diciptakan dengan menggunakan bahan radioaktif dan penggunaan senjata nuklir untuk aktivitas di ruang angkasa. Apabila peluncuran satelit tersebut mengalami kegagalan dan jatuh di wilayah negara lain secara otomatis dapat menimbulkan kerugian bagi negara-negara yang kejatuhan benda angkasa tersebut. Belum lagi, banyak benda-benda angkasa yang diluncurkan yang mengalami gagal fungsi (malfunction). Hal tersebut selalu dapat terjadi. Apalagi, bila peluncuran satelit bertenaga nuklir, yang pada umumnya satelit ini berorbit rendah sehingga satelit tersebut mudah mengalami gagal fungsi. Satelit pula memiliki umur (life-time), dan bila telah habis masanya akan menambah banyaknya satelit yang membahayakan benda angkasa yang masih berfungsi, 
maupun dapat jatuh dipermukaan bumi. Tidak hanya itu saja, kerugian dapat terjadi apabila benda angkasa yang hendak diluncurkan ke ruang angkasa mengalami kegagalan dalam peluncurannya. Dampak negatifnya dapat dirasakan oleh negara peluncur dan negara-negara lain yang terlibat dalam peluncuran benda angkasa tersebut, bahkan negara yang tidak ikut serta dalam kegiatan peluncuran. Berdasarkan hukum internasional, khususnya dalam Convention on International Liability for Damage Caused by Space Objects 1972, suatu negara dapat dimintakan pertanggungjawabannya bila benda angkasa milik negara yang telah menjadi sampah angkasa jatuh dan merugikan wilayah negara lain. Dalam konvensi internasional tersebut, tanggung jawab negara dalam peluncuran benda angkasa telah diatur sedemikian rupa, sehingga apabila negara peluncur menyebabkan kerugian di wilayah yuridiksi negara lain, maka negara peluncur tersebut wajib mematuhi prinsip-prinsip dan sistem tanggung jawab negara yang telah diatur dalam konvensi tersebut.

\section{Rumusan Masalah}

Berdasarkan uraian yang telah disampaikan, maka rumusan permasalahan yang akan dibahas dalam penelitian adalah :

1. Bagaimanakah pengaturan hukum internasional terhadap kegiatan di ruang angkasa ?

2. Bagaimanakah tanggung jawab negara peluncur atas kerugian yang ditimbulkan benda antariksa menurut Space liability Convention 1972 ?

\section{Pembahasan \\ State Responsibility dari Adanya Space Debris dalam Liability Convention 1972}

Dalam pasal III Liability Convention menjelaskan bahwa ketika kerugian terjadi terhadap benda ruang angkasa yang berada diluar permukaan bumi oleh benda antariksa milik negara peluncur lainnya, maka negara penyebab kerugian itu yang bertanggung jawab terhadap kerusakan tersebut. Tanggung jawab negara terhadap kerusakan tersebut adalah sebaliknya berdasarkan kesalahan (based on fault) dan sesuai dengan culpa gagasan klasik Romawi dan hukum perdata. Terhadap kerusakan seperti itu dua atau lebih pesawat ruang angkasa yang terlibat dan negara mereka memiliki resiko yang serupa. Tanggung jawab berdasarkan kesalahan harus dianggap sebagai pembenaran, karena para pihak berada dalam posisi yang seimbang berkaitan dengan kapasitas teknologi dan negosiasi diplomatik untuk mengklaim kompensasi dengan prosedur internasional. Peraturan yang sama juga berlaku dalam hukum udara. Rome Convention 1952 mengatur mengenai kerusakan yang terjadi di permukaan bumi mengacu pada prinsip tanggung jawab mutlak (absolute liability) sedangkan tanggung jawab terhadap tabrakan pesawat udara itu berdasarkan kesalahan (based on fault). Dalam konsep Convention on Aerical Collisions, yang disusun oleh komite hukum ICAO pada tahun 1964, menetapkan peraturan mengenai tanggung jawab berdasarkan kesalahan. Pasal VI (a) Liability 
Convention membahas mengenai pembagian tanggung jawab. Dijelaskan bahwa pembebasan dari tanggung jawab mutlak diberikan sejauh negara peluncur menyatakan bahwa kerusakan tersebut secara keseluruhan atau sebagian disebabkan oleh kelalaian berat atau kejahatan atau pelanggaran yang dilakukan dengan maksud untuk menyebabkan kerugian pada pihak negara penuntut atau terhadap orangorang, alam dan badan hukum atau negara yang mewakilinya.

Dengan ketentuan tersebut, semakin jelas bahwa negara peluncur dapat terhindar dari tanggung jawab penuh ketika ia dapat membuktikan bahwa bukan hanya negaranya yang bersalah dan kerugian yang timbul sepenuhnya merupakan kelalaian atau tindakan yang disengaja untuk menimbulkan kerugian terhadap negara penuntut. Namun jika negara tersebut tidak mampu membuktikan fakta tersebut, negara peluncur hanya bisa berhak untuk pembebasan dari sebagian tuduhan ketika kesalahan dapat dibuktikan ada pada kedua pihak. Pembebasan sebagian dari tuntutan dapat juga diberikan ketika negara peluncur dapat membuktikan bahwa negara penuntut telah lalai dalam mengurangi timbulnya kerusakan. Terdapat keadaan tertentu yang berada diluar kendali manusia atau biasa disebut force majeure. Dalam pasal VI konvensi ini tidak mengatur mengenai situasi atau keadaan tersebut. Beberapa delegasi dalam Legal Sub-Committee mengamati kekurangan ini selama perdebatan mengenai penyusunan Liability Convention ini. Pembebasan dari tanggung jawab seharusnya telah disediakan, terutama ketika terjadi bencana alam. Namun mayoritas dari delegasi tersebut mempertahankan opini bahwa timbul kekhawatiran jika menerapkan pembebasan tanggung jawab ini dapat menimbulkan penafsiran yang terlalu luas dan juga dapat meniadakan efek tanggung jawab mutlak (absolute liability). Konvensi ini mengatur perbedaan antara tanggung jawab secara individual dan tanggung renteng (joint and several liability). Tanggung renteng ini dilakukan oleh negara kepada negara pihak ketiga, ketika terjadi kerugian terhadap negara tersebut yang disebabkan oleh kecelakaan ruang angkasa yang terjadi diantara pesawat ruang angkasa negara-negara pihak pertama.59 Dalam kasus tanggung jawab renteng, negara pihak ketiga berhak untuk mendapatkan seluruh kompensasi dari negara-negara peluncur. Beban kompensasi tersebut harus dibagi antara negara-negara yang terlibat sesuai sejauh mana kesalahan mereka. Bila besar kesalahan masing-masing negara tidak dapat ditentukan, maka tanggung jawab untuk ganti rugi tersebut harus dibagi sama antar negara penyebab kerusakan. Pada akhirnya akan ada pembangian mengenai kompensasi tersebut. Selain memberikan kompensasi kepada negara pihak ketiga, Liability Convention juga mengatur cara lain dalam tanggung jawab renteng ini. Tanggung jawab ini tidak menyangkut mengenai kasus kerusakan yang dialami negara ketiga namun juga meliputi tanggung jawab ketika dua atau lebih negara bersamasama meluncurkan benda antariksa. Dalam kasus yang terakhir, semua negara yang terlibat dalam 
peluncuran akan renteng bertanggung jawab atas segala kerusakan yang disebabkan oleh benda antariksa mereka.

\section{Perhitungan Mengenai Kerusakan yang Ditimbulkan}

Dalam Pasal I Liability Convention arti kata "damage" berarti: "loss of life, personal injury or other impairment of health; or loss of or damage to property of States or of persons, natural or juridicial, or property of international intergovernmental organisations". Selanjutnya dalam pasal XII menjelaskan bahwa kerusakan dibayar dalam bentuk kompensasi yang ditentukan "sesuai dengan hukum internasional dan prinsipprinsip keadilan dan kesetaraan." Sejauh untuk memulihkan pihak terluka atau yang dirugikan dengan kondisi yang ada sebelum kerusakan terjadi. Dalam konvensi ini diatur beberapa jenis kerusakan yang harus dipertanggungjawabkan oleh negaranegara yang terlibat dalam peluncuran, yaitu:

\section{Kerusakan secara langsung (Direct Damage)}

Dalam pasal I konvensi ini menjelaskan mengenai empat hal spesifik yang termasuk kerusakan langsung, yaitu hilangnya nyawa, cedera pribadi, gangguan lain dari kesehatan, dan kehilangan atau kerusakan properti. Dalam konteks kerusakan tersebut, negara penuntut akan diperlukan untuk menunjukkan bahwa bahaya atau kerusakan yang dirasakan merupakan hasil langsung dari benda antariksa. Beberapa ahli telah mencatat bahwa "gangguan kesehatan" dapat berasal dari kontaminasi benda ruang angkasa serta adanya cedera fisik yang tidak perlu untuk memiliki kontak langsung dengan benda antariksa tersebut namun tetap menderita kerugian. Dalam konteks ini kerusakan yang menyebabkan radiasi disebabkan oleh masuk kembalinya Cosmos 954 secara tidak terduga,hal tersebut dapat dikategorikan sebagai kerusakan secara langsung, bahkan tanpa perlu bergantung pada prinsipprinsip NPS (Nuclear Power Source). Christol menyarankan bahwa kompensasi untuk kerusakankerusakan berikut yang dianggap sebagai kerusakan langsung:

1. Kehilangan waktu dan pendapatan dan penurunan kapasitas produktif;

2. Penghancuran atau perampasan penggunaan properti, termasuk di mana properti telah diberikan tidak layak untuk tujuan yang dimaksudkan;

3. Hilangnya keuntungan akibat gangguan bisnis

4. Kehilangan hak sewa;

5. Masalah medis, rumah sakit, dan keperawatan biaya yang terkait dengan luka yang diderita oleh orangorang alami;

6. Gangguan fisik dan mental;

7. Rasa sakit dan penderitaan;

8. Penghinaan;

9. Biaya yang terjangkau untuk perbaikan property;

10. Biaya yang dikeluarkan dalam tindakan diambil untuk mengurangi kerusakan yang disebabkan oleh benda antariksa.

\section{Kerusakan Secara Tidak} Langsung dan Kerugian Ekonomi

Dalam Liability Convention tidak dijelaskan mengenai kerusakan tidak langsung atau konsekuensial. Pasal II dan III konvensi ini, keduanya 
merujuk pada kerusakan yang disebabkan oleh benda antariksa. Negara Hungaria dan Uni Soviet menentang penafsiran mengenai kemungkinan adanya pemulihan terhadap kerusakan secara tidak langsung, sementara Italia dan Jepang menyetujui tafsiran tersebut. Pada akhirnya, hal tersebut menjadi sebuah pertanyaan, kata "disebabkan" dalam konvensi ini harus ditafsirkan sebagai pengarah perhatian pada kebutuhan untuk beberapa hubungan sebabakibatl antara kecelakaan dan kerusakan, sedangkan dalam penafsiran secara luas yaitu agar klaim dapat ditentukan sesuai jenis kerusakan atau kerugian. Terdapat beberapa teori yang mendukung proposisi bahwa kalimat "caused by" tidak memerlukan lebih dari satu hubungan sebab-akibat antara objek ruang dan kerusakan sebagai Liability Convention meliputi kerusakan baik langsung dan tidak langsung. Dalam konteks kasus Cosmos-954, misalnya, Peter Hannapel menyarankan agar biaya penyelidikan dan pemulihan yang dikeluarkan oleh Kanada, serta biaya yang dikeluarkan untuk mengurangi kerusakan secara tidak langsung (indirect damage) untuk tujuan Pasal VII Outer Space Treaty dan Liability Convention. Jika disimoulkan secara logis, maka negara hanya akan dapat menanggung biaya yang dikeluarkan dalam hal mengurangi kerusakan yang ada dalam kontrak yang diatur serta untuk mencegah kerusakan yang akan terjadi di masa depan.

\section{Kerusakan Moral}

Dalam hukum internasional, kerusakan atau kerugian moral diartikan sebagai cedera terhadap martabat atau kedaulatan negara, seperti jika terjadi pelanggaran kewajiban terhadap perjanjian yang tidak menghasilkan cedera material namun negara yang melanggar diharapkan untuk membayar denda terhadap kerugian yang timbul. Selain itu, rasa sakit dan penderitaan dan kehilangan kemampuan untuk menikmati hidup juga dapat dianggap kerusakan moral. Istilah "keadilan" tidak merujuk kepada prinsip hukum keadilan pada umumnya melainkan merujuk kepada "keadilan moral". Dengan kata lain, penilaian terhadap kerusakan adalah tugas yang harus dilakukan dengan mengacu pada kerugian yang dilami penderita daripada melalui penerapan prinsipprinsip internasional maupun nasional. Amerika Serikat telah lama menyatakan pandangan bahwa kerusakan moral tercakup dalam Liability Convention dan jika klaim dibuat di masa depan dengan Amerika Serikat, klaim tersebut akan mencakup komponen mengenai kerusakan. Sementara kerusakan moral yang dilakukan terhadap pribadi atau individu dapat membentuk mengakibatkan hubungan sebab akibat dengan benda antariksa, namun sulit untuk mengetahui bagaimana kerusakan moral yang diderita oleh negara akan dipulihkan jika dihubungkan dengan akibat yang disebabkan peluncuran ruang angkasa, mengingat penyebab kerusakan oleh benda antariksa tersebut bukan merupakan "prima facie" tetapi lebih kepada pelanggaran terhadap prinsip yang ada dalam hukum perjanjian.

\subsection{Prosedur Klaim Terhadap Kerusakan}


Dalam article IX Liability Convention menyatakan bahwa klaim untuk kompensasi kerusakan akan disampaikan kepada keadaan peluncuran melalui saluran diplomatik, yang meliputi yang ada representasi diplomatik bilateral melalui negara lain yang memiliki hubungan diplomatik dengan negara launching atau sekretaris jenderal PBB. Jika ada kompensasi yang perlu dibayar, dengan pemanfaatan mekanisme diplomatik tersebut, negara penuntut dan negara peluncur dapat menegosiasikan penyelesaian mengenai jumlah kompensasi yang tepat. Jika negara penuntut dan negara peluncur gagal untuk menyelesaikan sengketa dalam waktu satu tahun proses klaim, salah satu pihak dapat meminta pembentukan suatu komisi penuntut, komisi penuntut ini terdiri dari tiga anggota yaitu satu ditunjuk oleh negara peluncur, satu ditunjuk oleh negara penuntut, dan ketua komisi penuntut yang akan dipilih bersama oleh kedua belah pihak. Jumlah komisi tidak akan meningkat jika ada lebih dari satu negara penuntut atau negara, namun mereka secara kolektif menunjuk satu anggota dari klaim komisi. Negara penuntut dan negara peluncur diberikan waktu dua bulan dari waktu permintaan pembentukan komisi penuntut untuk menunjuk para anggota komisi penuntut dan empat bulan untuk menyetujui penunjukan ketua komisi penuntut tersebut. Jika para pihak gagal untuk menunjuk anggotanya dari komisi penuntut dalam waktu yang diberikan, maka pihak lain dapat meminta ketua untuk membentuk komisi penyelesaian tuntutan yang beranggotakan tunggal. Jika pihak gagal menyepakati pemlihan ketua, salah satu pihak dapat meminta sekretaris Amerika Serikat untuk menunjuk ketua komisi penuntut. Komisi penuntut dibebankan dengan satu tugas saja yaitu memutuskan manfaat klaim untuk kompensasi dan menentukan jumlah kompensasi yang harus dibayar, sesuai dengan pasal XII dari Liability Convention. Komisi penuntut menentukan prosedur sendiri, kecuali bahwa keputusan tersebut diputuskan oleh suara mayoritas. Salah satu kritik terkuat yang dibuat terhadap proseudr yang dilakukan oleh komisi penuntut sebagaimana tercantum dalam Liability Convention adalah bahwa, kecuali para pihak menyetujui lain, keputusan yang dibuat oleh komisi penuntut ini tidak lebih dari sifat yg dipuji, yang para pihak perlu pertimbangkan dengan itikad baik. Seperti yang disarankan oleh beberapa komentator, bahwa ini berarti tidak lebih dari sebuah prosedur konsiliasi terjamin dalam Liability Convention dan jika pihak setuju untuk terikat oleh komisi penuntut maka prosedur tersebut akan menyerupai pengadilan arbitrase.

\subsection{Praktek Tanggung Jawab Keantariksaan Negara-Negara Ketentuan Terkait Tanggung Jawab}

Liability

Convention membebankan tanggung jawab internasional untuk kerusakan yang disebabkan oleh benda-benda ruang angkasa yang diluncurkan oleh negara peluncur, beberapa negara yang memiliki pemerintahan dengan sektor swasta aktif telah menyadari kebutuhan untuk membebankan tanggung jawab ini kepada operator 
swasta melalui undang-undang nasional. Dalam hal ini, kombinasi antara kewajiban untuk mengotorisasi dan mengawasi kegiatan ruang angkasa yang dilakukan oleh pihak non-pemerintah berdasarkan Pasal VI dan VII dari Outer Space Treaty. Dalam kedua pasal ini dijelaskan bahwa setiap negara memiliki tanggung jawab internasional terhadap aktivitas ruang angkasa nasional. Sebagian besar undangundang nasional yang ada berlaku mengenai kegiatan ruang angkasa yang dilakukan pihak swasta membebankan beberapa rezim ganti rugi untuk mentransfer risiko kerugian dari pemerintah ke operator swasta. Perlu dicatat bahwa keberadaan undang-undang nasional negara yang berurusan dengan tanggung jawab tidak mempengaruhi hak dan tanggung jawab mereka di tingkat internasional. Negara tetap bertanggung jawab secara internasional sesuai dengan Liability Convention dan undang-undang yang tidak lebih dari untuk memberikan dasar hukum yang ditempuh oleh negara yang kemudian berusaha untuk mendapatkan kembali kompensasi yang dibayarkan dari operator swasta melalui jalur hukum nasional.

\subsection{Praktek Negara-Negara Dalam Menyelesaikan Sengketa Munurut Liability Convention 1972}

Dalam peluncuran suatu benda ruang angkasa, tidak selalu menimbulkan dampak positif, tentu saja terdapat banyak manfaat bagi suatu negara terutama negara peluncur dan negara-negara yang terkait dengan peluncuran, namun kita tidak dapat memungkiri bahwa kecelakaan akibat peluncuran benda ruang angkasa itu tetap ada. Kecelakaan terhadap negara pihak ketiga ataupun pesawat udara suatu negara yang sedang beroperasi sehingga menimbulkan tanggung jawab mutlak bagi negara peluncur. Kecelakaan ini menimbulkan kerusakan yang kemudian menjadi suatu sengketa antar negara, pada umumnya penyelesaian sengketa yang diatur dalam hukum ruang angkasa ini sama dengan penyelesaian sengketa dalam hukum internasional. Hukum ruang angkasa (space law) merupakan bagian dari hukum internasional sehingga penyelesaian sengketa dalam dilakukan melalui ICJ (International Court of Justice), proses ini dapat dilakukan ketika salah satu pihak melaporkan hal tersebut dan proses ini dapat dilakukan jika kedua pihak merupakan anggota PBB. Penyelesaian sengketa juga dapat dilakukan dengan cara arbitrase. Arbitrase merupakan proses penyelesaian diluar pengadilan, sedangkan ICJ (International Court of Justice) adalah mahkamah resmi namun bukan proses peradilan biasa, dalam ICJ kasus harus diajukan oleh salah satu pihak dan proses itu disetujui oleh pihak lawannya. Dalam Liability Convention diatur proses tuntutan rugi melalui komisi penuntut (claim commision) jika tidak terdapat penyelesaian penuntutan dalam jangka waktu satu tahun terhitung saat penuntut menyerahkan dokumen tuntutannya, proses di komisi penuntut ini pada dasarnya sama dengan proses arbitrase namun komisinya bukan hakim tetapi ditunjuk oleh salah satu pihak dan disetujui oleh pihak lain dan 
penunjukan harus melalui saluran diplomatik.

\subsection{Pengaturan Hukum Internasional Mengenai Kegiatan di Ruang Angkasa 1. Proses Pembentukan Hukum Ruang Angkasa}

Proses pembentukan Hukum Ruang Angkasa didasarkan terutama kepada Hukum Internasional dan kerja-sama internasional. Oleh karena itulah peranan hukum Internasional sangat menentukan. Seperti juga hukum laut maupun udara yang memiliki rezim hukum tersendiri, ruang angkasa pun memiliki rezim hukumnya sendiri. Hukum ruang angkasa dapat diartikan sebagai kumpulan dari berbagai hukum internasional yang mengatur hubungan antar negara, maupun dengan organisasi internasional dalam ruang lingkup aktivitas keruangangkasaan, dalam suatu rezim Hukum Internasional untuk luar angkasa dan benda-benda luar angkasa yang bersesuaian dengan prinsip-prinsip Hukum Internasional. Tahap pertama proses pembuatan Hukum Ruang Angkasa ini ditandai oleh pengajuan serentetan resolusi oleh Majelis Umum. Resolusi ini meliputi petunjukpetunjuk dan caracara meningkatkan kerja-sama internasional serta penetapan prinsipprinsip dasar tentang peraturannya. Pada sidang yang dilaksanakan tahun 1965 dihasilkan resolusi Majelis Umum PBB tertanggal 21 Desember 1965, yaitu resolusi 2130 (XX) yang menyangkut prinsip-prinsip hukum yang menguasai kegiatan di negara ruang angkasa. Selanjutnya pada tanggal 16 Juni 1966, atas usul Amerika Serikat dan Uni Soviet diajukan konsep Treaty on Principles Governing the Activities of States in the Exploration and Use of Outer Space, the Moon and other celestial bodies. Dengan aklamasi sebuah treaty dalam resolusi no. 2222 (XX) dan di tanda-tangani di Washington, London, Moscow pada tanggal 27 Januari 1967. Treaty yang ditandatangani pada tanggal 27 Januari 1967 tersebut mengatur tentang status ruang angkasa, Bulan dan Benda-benda langit lainnya, serta mengatur usaha-usaha dan kegiatan manusia di ruang angkasa sekaligus menetapkan segala hak dan kewajiban negara-negara. Treaty tersebut selanjutnya disebut Space Treaty 1967. Space treaty 1967 tersebut merupakan hukum dasar bagi penciptaan hokum-hukum dalam masalah aktivitas mannusia di ruang angkasa termasuk Bulan dan bendabenda langit lainnya. Atas dasar prinsip-prinsip yang terkandung di dalam Space Treaty 1967 tersebut, hingga kini Perserikatan BangsaBangsa melalui Komite Pemanfaatan Ruang Angkasa untuk Tujuan Damainya (United Nation Comitee on the Peaceful Uses of Outer Space yang disingkat UN-COPUOS) telah menciptakan suatu aturan hukum internasional mengenai kegiatan ruang angkasa, yaitu:

a. Agreement on the Rescue of Astronauts, the return of Astronauts and the return of Objects launched into Outer Space, yang ditandatangani di London, Moscow, dan Washington pada tanggal 22 April 1968.
b. Convention
of
International Liability for Damage Caused by Space Objects, yang 
ditandatangani pada tanggal 28 Maret 1972.

c. Convention concerning the Registration of Objects launched into Space for

Exploration or Use of Outer Space tahun 1975, dan

d. Moon Agreement tahun 1979.

\subsection{Tanggung jawab Negara atas} Kerugian yang Ditimbulkan Benda Antariksa Menurut Liability Convention 1972

Tidak ada suatu negara pun yang dapat menikmati hak-haknya tanpa menghormati hak-hak yang dimiliki oleh negara lain. Oleh karena itu, selain patut memperhatikan kepentingan bangsa atau negara lain, seharusnyalah segala tindakan dan hubungan antara berbagai bangsa / negara itu berlandaskan pada normanorma Hukum Internasional. Apabila ada suatu negara yang dengan sengaja melanggar kewajiban internasional maka negara tersebut dapat dikenai kewajiban untuk memperbaiki keadaan pelanggaran yang telah dilakukan oleh suatu negara. Dengan kata lain, negara pelanggar tersebut memiliki pertanggungjawaban internasional akibat tindakannya yang merugikan negara lain. Bila dihubungkan dengan masalah tanggung jawab negara dalam keterkaitan aktivitasnya di ruang angkasa, maka jelaslah negara yang melakukan kegiatan atau memanfaatkan sumber daya ruang angkasa tidak boleh merugikan negara lain. Konsekuensi logis dari hal ini adalah bahwa negara pemilik benda angkasa wajib bertanggung jawab terhadap negara yang dirugikan. Tentang kemungkinan kerusakan yang diakibatkan jatuhnya benda-benda angkasa buatan manusia serta dampak negatif dari segenap kegiatan di ruang angkasa, ada 2 perjanjian internasional yang memuat ketentuan-ketentuan dasar mengenai tanggung jawab dalam hukum ruang angkasa yaitu Treaty on Principles Governing the Activities in the Exploration and Use of Outer Space, including Moon and Other Celestial Bodies ("Space Treaty 1967”); dan Convention on International Liability For Damage Caused by Space Objects, 1972 ("Liability Convention 1972”).

Space Liability Convention 1972 ini mengandung 4 lingkup atau sudut pandang, yaitu lingkup geografis, lingkup benda (material), lingkup fungsional/personal, dan lingkup waktu. Dengan meninjau keempat susut pandang ini, maka dapat terlihat hal-hal seperti: di wilayah ruang mana saja konvensi ini dapat berlaku; dapat dikenakan pada siapa saja serta apa saja yang menjadi tujuan dari konvensi dan akhirnya dapat pula dilihat waktu berlakunya konvensi ini. Lingkup geografis membawa kita pada pengertian tentang wilayah berlakunya konvensi. Jika kita lihat isi Artikel II dari Liability Convention 1972 yang menyatakan bahwa: "A Launching State shall be absolutely liable to pay compensation for damage caused by its space object on the surface of the earth or to aircraft in flight." Dengan demikian maka jelaslah bahwa Liability Convention 1972 itu mempunyai wilayah huni atau dapat diterapkan terhadap segenap kerugian yang disebabkan oleh benda-benda angkasa baik kerugian itu terjadi di 
wilayah darat, laut, udara dan berlaku pula di ruang angkasa serta laut bebas. Dengan lingkup personal dimaksudkan untuk mengetahui pihak mana saja yang dapat terlibat di dalam pelaksanaan konvensi. Lingkup fungsional dan material dapat terlihat dari Pasal I ayat (b) mengenai apa yang dimaksud dengan negara peluncur. Negara peluncur adalah negara yang harus bertanggung jawab secara internasional atas kerugian yang diderita sebagai akibat jatuhnya benda-benda ruang angkasa (space objects) di permukaan bumi atau pada pesawat udara yang sedang melakukan penerbangan rutin. Dalam kajian ini jelas bahwa Liability Convention 1972 merupakan suatu ketentuan hukum yang mengatur tentang pertanggungjawaban negara dalam aktivitasnya di ruang angkasa atau aktivitasnya berkenaan dengan peluncuran benda-benda ruang angkasa. Peninjauan konvensi dari lingkup waktu terlihat dalam Artikel XXVI yaitu menyangkut berlakunya konvensi yang dapat ditinjau kembali setelah 10 tahun dan setelah 5 tahun berlakunya konvensi tersebut dapat ditinjau kembali dengan catatan harus mendapatkan persetujuan dari $1 / 3$ negara peserta konvensi.

\subsection{Prinsip Tanggung Jawab Pada Jatuhnya Sampah Luar Angkasa Treaty on Principles} Governing the Activities of States in the Exploration and Use of Outer Space, Including the Moon and other Celestial Bodies 1967, menjelaskan bahwa setiap negara tanpa diskriminasi dapat mengeksplorasi ruang angkasa dengan tujuan damai. Kegiatan eksplorasi dapat dilakukan dengan bebas bagi seluruh negara yang telah siap dengan kemajuan teknologi yang dimilikinya asalkan tetap dengan tujuan damai, yang tidak didominasi dengan tujuan militer atau politik. Dalam konvensi tersebut juga dijelaskan bahwa suatu negara wajib untuk bertanggung jawab secara internasional apabila kegiatannya atau benda angkasanya menyebabkan kerugian. Konvensi ini mempunyai perpanjangan tangan, yaitu Convention on International Liability for Damage caused by Space Objects 1972. Dalam Convention on International Liability for Damage caused by Space Objects 1972 dijelaskan bahwa tiap-tiap negara secara internasional bertanggung jawab atas kegiatan yang dilakukan oleh negara tersebut. Tanggung jawab internasional dalam hukum angkasa akan timbul apabila negara peluncur menimbulkan kerusakan. Kerusakan dijabarkan dalam pasal 1 Convention on International Liability for Damage caused by Space Objects 1972. Lebih lanjut, prinsip dasar tanggung jawab secara internasional disebutkan dalam pasal II dan pasal III dalam Convention on International Liability for Damage caused by Space Objects 1972. Pasal II. Prinsip yang terdapat dalam pasal II menyebutkan bahwa negara peluncur mutlak bertanggung jawab atas kerusakan yang ditimbulkan akibat benda angkasanya. Negara penuntut (claimant state) ialah negara yang dirugikan.

Negara penuntut tidak perlu membuktikan kesalahan negara peluncur agar negara peluncur bertanggung jawab. Negara penuntut hanya perlu memberitahukan kerusakan yang ditimbulkan oleh benda angkasa milik negara peluncur. 
Dalam prinsip ini pula, negara penuntut dianggap tidak mempunyai kemampuan untuk membuktikan kesalahan si negara peluncur, karena biasanya, negara yang terlibat dalam kegiatan pemanfaatan ruang angkasa merupakan negara-negara yang memiliki teknologi tinggi. Prinsip ini diaplikasikan pada kerusakankerusakan yang timbul akibat benda angkasa milik negara peluncur yang jatuh ke permukaan bumi, atau pun terhadap pesawat udara dalam penerbangan. Prinsip kedua dalam Convention on International Liability for Damage caused by Space Objects 1972 ialah tanggung jawab atas dasar kesalahan yang terdapat dalam pasal III. Dalam bahasa inggris prinsip tanggung jawab karena kesalahan disebut sebagai liability based on fault. Pasal III terdapat prinsip tanggung jawab atas dasar kesalahan yang mengharuskan suatu negara penuntut membuktikan kesalahan yang disebabkan oleh negara peluncur. Kesalahan tersebut dapat berupa kerusakan, sama halnya dengan prinsip tanggung jawab mutlak. Namun, negara penuntut diharuskan membuktikan terlebih dahulu kesalahan yang dituntutkan kepada negara peluncur. Artinya, bila suatu negara penuntut mengalami kerugian akibat kerusakan yang ditimbulkan oleh benda angkasa negara peluncur, maka negara penuntut tersebut harus membuktikan bahwa kerusakan tersebut memang benar disebabkan oleh benda angkasa negara peluncur. Dalam prinsip ini, negara yang melibatkan diri dalam kegiatan pemanfaatan ruang angkasa dinilai telah memahami bahaya yang timbul akibat kegiatannya. Oleh sebab itu, negara yang merasa dirugikan harus membuktikan kesalahan negara peluncur. Namun, perlu diperjelas bahwa prinsip ini ditekankan bagi negara peluncur dan kerusakan-kerusakan yang terjadi di mana saja selain di permukaan bumi.

\section{A. Bentuk-Bentuk Pertanggungjawaban Pelucur}

Bentuk-bentuk pertanggung jawaban negara peluncur dapat dirumuskan dan dibagi kedalam empat macam klasifikasi yaitu:

1. Tanggung jawab secara mutlak (absolute liability)

2. Tanggung jawab berdasarkan kesalahan (liability based on fault)

3. Tanggung jawab secara bersama antar negara dan sebagian negaranegara (joint and several liability), dan

4. Pengecualian atau pembebasan dari tanggung jawab (exoneration from liability)

- Absolute liability ( Tanggung Jawab secara mutlak )

Negara peluncur harus bertanggung jawab secara mutlak atas segala kerugian yang ditimbulkan oleh benda ruang angkasanya terhadap negara lain baik terhadap benda dan manusia, badan hukum maupun terhadap negara lain baik tehadap harta benda dan manusia, badan hukum manapun terhadap kerugian yang diderita oleh suatu pesawat udara dalam penerbangan sebagai akibat dari pelaksanaan kegiatan keantariksaan oleh negara peluncur. 
- Tanggung jawab berdasarkan kesalahan (liability based on fault)

Absolute liability (tanggung jawab mutlak) terbatas pada tanah, air, dan ruang angkasa, sedangkan subjek pada prinsip pertanggungjawaban berdasarkan atas kesalahan (fault liability) itu misalnya seperti pada suatu kejadian yang memungkinkan bahwa ada kerugian yang disebabkan oleh benda ruang angkasa di ruang angkasa.

- Joint and Several Liability (Tanggung jawab antara gabungan ataubeberapa negara)

Adalah dua buah bentuk pertanggung jawaban antara gabungan atau beberapa Negara, Meliputi pertanggungjawaban karena kerusakan yang diakibatkan oleh benda-benda ruang angkasa yang diluncurkan oleh lebih dari satu negara

- Pembebasan dari tanggung jawab (Exoneration From Liability)

Pembebasan tanggung jawab secara mutlak ini harus diberikan sejauh negara peluncur menyatakan bahwa kerusakan tersebut secara keseluruhan atau sebagian disebabkan oleh kelalaian berat atau kejahatan atau pelanggaran yang dilakukan dengan maksud menyebabkan kerugian pada pihak penuntut atau terhadap orangorang, alam dan badan hukum atau negara yang mewakilinya.

B. Tanggung Jawab Negara Peluncur terhadap Sampah Ruang Angkasa yang Dihasilkan dari Kegiatan Ruang Angkasa

Hukum internasional telah memiliki suatu instrumen yang memberikan pedoman terhadap negara ataupun pihak yang ingin menggunakan ruang angkasa sebagai lokasi kegiatannya. Peraturan tersebut berjudul Treatyon Principles Governingthe Activitiesof Statesinthe Explorationand Use of Outer Space Including the Moon and Other Celestial Bodies, atau lebih sering disebut sebagai Outer space treaty 1967. Konvensi ini menyetujui prinsip-prinsip untuk ditaati para negara pengguna ruang angkasa. Pada Outer space treaty 1967 yang menjadi induk prinsip-prinsip berkegiatan negara di ruang angkasa, serta bahan hukum primer pada penelitian ini, pasal VI menyebutkan: "States Parties to the Treaty shall bear international responsibility for national activities in outer space, including the Moon and other celestial bodies, whether such activities are carried on by governmental agencies or by nongovernmental entities, and for assuring that national activities are carried out in conformity with the provisions set forth in the present Treaty. The activities of nongovernmental entities in outer space, including the Moon and other celestial bodies, shall require authorization and continuing supervision by the appropriate State Party to the Treaty. When activities are carried on in outer space, including the Moon and other celestial bodies, by an international organization, responsibility for compliance with this Treaty shall be borne both by the international organization and by the States Parties to the Treaty participating in such organization." Atau jika diterjemahkan, negara anggota perjanjian ini mengemban tanggung jawab internasional dalam 
aktivitasnya di ruang angkasa baik kegiatan tersebut dilakukan oleh pemerintah ataupun bukan.

Jika kegiatan di ruang angkasa dilakukan bukan oleh pemerintah maka tetap diperlukan adanya ijin serta pengawasan oleh Negara peserta perjanjian Sementara itu pada pasal VII disebutkan "Each State Party to the Treaty that launches or procures the launching of an object into outer space, including the Moon and other celestial bodies, and each State Party from whose territory or facility an object is launched, is internationally liable for damage to another State Party to the Treaty or to its natural or juridical persons by such object or its component parts on the Earth, in air space or in outer space, including the Moon and other celestial bodies." Atau jika diterjemahkan, semua negara anggota perjanjian yang melakukan peluncuran benda angkasa, secara internasional mengemban tanggung jawab atas segala kerusakan yang mengakibatkan kerugian pada Negara lain di wilayah bumi, udara maupun di wilayah ruang angkasa itu sendiri Pada dua pasal ini terdapat pembedaan antara istilah "international responsibility" dan "internationally liable". Hal ini memperkuat pendapat sebelumnya mengenai dua macam tanggung jawab yang lahir pada hukum internasional Untuk kepentingan menjawab rumusan permasalahan yang pertama ini, tanggung jawab yang dimaksud adalah tanggung jawab pada pengertian pertama, yakni kewajiban untuk melaksanakan perjanjian internasional Pasal VI menyebutkan bahwa semua kegiatan nasional yang dilakukan oleh suatu negara di ruang angkasa menjadikannya memiliki tanggung jawab secara internasional Jika kemudian Pasal VI tersebut dibagi ke dalam beberapa unsur maka akan menjadi seperti berikut:

1. Bahwa setiap negara bertanggung jawab atas aktivitas negara di ruang angkasa baik oleh badan hukum publik maupun privat

2. Untuk memastikan supaya aktivitas negara sesuai dengan apa yang diinginkan oleh Outer space treaty, terutama Pasal III, dan juga Hukum Internasional

3. Untuk memberikan ijin dan pengawasan yang berkesinambungan atas aktivitas organisasi nonpemerintah di ruang angkasa

4. Untuk membagi tanggung jawab internasional atas kegiatan di ruang angkasa oleh Organisasi Internasional di mana suatu negara tersebut berpartisipasi.

Mengacu pada Pasal VI maka sesungguhnya setiap negara yang melakukan aktivitas di ruang angkasa bertanggung jawab atas semua kegiatan yang dilakukan. Hal ini semakin memperkuat bahwa setiap kegiatan di ruang angkasa harus tetap dalam pengawasan dan perawatan yang berkesinambungan. Hal ini semakin diperkuat dengan adanya Pasal VII yang menyebutkan bahwa kegagalan negara di ruang angkasa dalam melaksanakan kewajibannya akan menghasilkan tanggung jawab yang menyebabkan timbulnya ganti rugi. Maka jelaslah bagaimana tanggung jawab negara terhadap kegiatannya di ruang angkasa. Unsur 
kedua dari Pasal VI adalah aktivitas negara di ruang angkasa harus tunduk pada ketentuan yang ada di Outer space treaty dan juga ketentuan hukum internasional pada umumnya. Keharusan untuk tunduk pada Outer space treaty berarti keharusan untuk tunduk pada prinsip-prinsip yang ada. Terdapat beberapa prinsip yang ada di Outer space treaty 1967 antara lain:

a. Prinsip non-diskriminasi, yaitu bahwa antariksa termasuk bulan dan benda langit lainnya harus dimanfaatkan untuk kepentingan semua bangsa tanpa membeda-bedakan tingkat ekonomi dan teknologi di antara mereka, semua negara berhak untuk melakukan aktivitas di dalamnya

b. National non-apropriation principle, dengan prinsip ini maka tertutuplah setiap usaha negara untuk melakukan klaim kepemilikan atas bagian manapun dari antariksa termasuk bulan dan benda langit lainnya baik melalui kedaulatan maupun pendudukan

c. Rule of Law, bahwa kegiatan negaranegara dalam kaitannya dengan antariksa harus berlandaskan hukum internasional termasuk piagam PBB demi memelihara perdamaian dan keamanan dunia

d. Prinisp Perdamaian, bahwa negara tidak diperbolehkan meletakkan senjata berbentuk apapun yang dapat mengakibatkan kerusakan masal maupun senjata jenis apapun yang berbahan nuklir. Tidak diperbolehkan pula melengkapi benda angkasanya dengan peralatan demikian

e. Prinsip kemanusiaan, bahwa setiap negara harus saling membantu apabila kemudian terjadi sebuah kecelakaan, panggilan bantuan, atau pendaratan darurat oleh astronot yang terjadi di wilayah laut bebas atau wilayah territorial sebuah Negara.

f. Prinsip tanggung jawab, bahwa semua negara dibebani tanggung jawab untuk menaati semua isi dari perjanjian ini dan untuk memberikan ganti rugi apabila aktivitasnya di ruang angkasa membahayakan pihak yang lainnya

g. Prinsip persamaan, yaitu bahwa antariksa termasuk bulan dan benda langit lainnya dinyatakan bebas untuk dimanfaatkan setiap negara atas dasar persamaan

h. Prinsip kerjasama, yaitu bahwa kerja sama antar negara harus dilandasi kebebasan untuk melakukan penelitian ilmiah atas antariksa termasuk bulan dan benda langit lainnya

i. Prinsip keterbukaan, yaitu setiap negara yang melakukan kegiatan di ruang angkasa harus memberikan kesempatan bagi wakil negara lain yang ingin melakukan kunjungan atau pembelajaran bersama dengan dasar timbal 
balik dan saling menguntungkan.

Melihat pada prinsip-prinsip yang lahir dari Outer space treaty, salah satu prinsip utama adalah larangan kepemilikan terhadap ruang angkasa seperti yang terdapat pada pasal II yang berbunyi seperti berikut "Outer space, including the Moon and other celestial bodies, is not subject to national appropriation by claim of sovereignty, by means of use or occupation, or by any other means." Prinsip larangan kepemilikan terhadap ruang angkasa mempertegas bahwa sesungguhnya ruang angkasa dapat digunakan oleh negara manapun dan tidak ada negara yang berhak melakukan klaim kedaulatan di ruang angkasa. Ruang angkasa bebas digunakan untuk kepentingan bersama umat manusia atau lebih dikenal dengan istilah common heritage of mankind. Konsep common heritage of mankind atau milik bersama umat manusia, merupakan sebuah konsep yang sifatnya umum dalam keberadaan dan perkembangan hukum internasional. Konsep ini menjelaskan bahwa terdapat suatu wilayah yang mana wilayah tersebut menjadi milik bersama umat manusia. Sumber daya yang dihasilkan di wilayah tersebut dapat digunakan oleh semua orang dan untuk keuntungan semua orang. Hasil dari wilayah tersebut diharapkan dapat memenuhi kebutuhan dari negara berkembang maupun kebutuhan bagi generasi yang akan dating. Hal ini dimaksudkan supaya penggunaan wilayah tersebut dapat digunakan untuk pembangunan yang berkelanjutan utamanya terhadap keberlangsungan dan keberadaan sumber daya yang dihasilkan.
Beberapa poin dasar dari wilayah yang disebut kepentingan bersama umat manusia itu antara lain:

a. Tidak ada satu negara atau seorangpun yang dapat memiliki wilayah maupun sumber daya alamnya. Wilayah maupun sumber daya alam tersebut dapat digunakan, namun tidak untuk dimiliki. Hal ini dikarenakan wilayah tersebut adalah bagian dari warisan bagi dunia internasional dan menjadi milik semua umat manusia. Ini melindungi wilayah tersebut dari segala kepentingan negara manapun yang ingin memperlebar wilayah yurisdiksinya.

b. Penggunaan wilayah tersebut harus didasarkan pada kemauan untuk bekerja sama antar pengguna demi keuntungan seluruh umat manusia. Hal ini dimaksudkan untuk membangun sebuah hubungan kepercayaan antar negara yang melindungi kepentingan seluruh umat manusia daripada kepentingan maupun keuntungan sekelompok orang saja. Setiap negara yang memanfaatkan wilayah ini harus saling berbagi atas keuntungan yang diterima akibat aktivitasnya.

c. Wilayah harus digunakan untuk kepentingan perdamaian. Kegiatan militer pada wilayah ini tidak diperbolehkan

d. Penggunaan wilayah tersebut harus terus dipelihara supaya dapat digunakan hingga masa yang akan dating. Termasuk 


\begin{tabular}{|c|c|}
\hline \multicolumn{2}{|c|}{ perlindungan } \\
\hline terhadap & ekologi \\
\hline kesamaan & antara \\
\hline $\begin{array}{l}\text { sekarang } \\
\text { berikutnya. }\end{array}$ & dan \\
\hline
\end{tabular}

Pada poin terakhir jelas dijelaskan bahwa penggunaan wilayah common heritage of mankind, dalam hal ini ruang angkasa, harus tetap memperhatikan kegunaannya di kemudian hari Bukan itu saja, kegiatan di ruang angkasa juga harus memberikan perlindungan terhadap keadaan lingkungan. Dalam hal ini bukan saja lingkungan ruang angkasa namun juga lingkungan bumi secara keseluruhan Keberadaan sampah ruang angkasa yang semakin banyak jumlahnya adalah hasil dari makin maraknya kegiatan negara di ruang angkasa Sampah ruang angkasa pada tulisan ini adalah benda-benda angkasa yang sudah tidak berfungsi lagi namun tetap dibiarkan berada di orbit bumi. Benda angkasa seperti satelit, stasiun ruang angkasa atau mesin peluncur yang sudah tidak terpakai lagi itulah yang kemudian disebut sebagai sampah ruang angkasa. Benda-benda tersebut tidak jatuh ke bumi namun tetap mengorbit dengan beberapa kemungkinan yang membahayakan. Sampah ruang angkasa dalam pengertian ini antara lain:

a. Satelit yang telah habis masa pakainya

b. Kendaraan ruang angkasa yang tidak berfungsi lagi

c. Partikel hasil peluncuran benda angkasa yang sudah tidak terpakai

d. Pecahan benda angkasa sisa misi ruang angkasa

e. Kepingan atau serpihan benda angkasa
Dalam kasus keberadaan sampahsampah ruang angkasa yang bertebaran di orbit bumi menunjukkan bahwa negara pengguna ruang angkasa tidak menjalankan kewajibannya dengan baik. Menurut prinsip di Outer space treaty disebutkan bahwa wilayah ruang angkasa adalah milik bersama seluruh umat manusia (common heritage of mankind). Hal ini menunjukkan bahwa segala kegiatan negara tetap harus menghormati hakhak negara lain atas wilayah tersebut, karena semua negara berhak untuk beraktivitas di dalamnya. Jika keberadaan sampah ruang angkasa semakin banyak, dan efek tabrakan yang ditakutkan terjadi, bukan hanya benda angkasa saja yang terancam keberadaannya. Benda angkasa yang jatuh ke bumi juga dapat mengancam lingkungan di permukaan bumi. Hal inilah yang tidak diinginkan untuk terjadi. Jika merujuk pada pasal VII, telah dibuat sebuah perjanjian internasional lain yang bertujuan untuk memberikan perlindungan terhadap kerugian hasil berkegiatan di ruang angkasa. Namun meskipun ada perlindungan yang telah diakomodir di Liability Convention 1972, tetap saja tidak ada satu negarapun yang berharap benda angkasa menimpa wilayah negaranya. Maka dari itu keberadaan sampah ruang angkasa yang semakin banyak jumlahnya harus dikontrol keberadaannya. Pada saat ini, dari masih banyaknya jumlah benda angkasa tidak aktif yang ada di orbit bumi, dapat disimpulkan bahwa negara peluncur masih belum mampu menjalankan kewajibannya seperti apa yang diamanahkan oleh Outer space treaty 1967 sebagai dasar hukum ruang angkasa. 


\subsection{Peraturan Baru Diperlukan untuk Mengontrol Keberadaan Sampah Ruang Angkasa}

Outer space treaty sebagai dasar prinsip kegiatan negara di ruang angkasa telah berusia 48 tahun Selama 48 tahun itu pula teknologi negara untuk berkegiatan di ruang angkasa telah meningkat dengan pesat. Bersamaan dengan meningkatnya kegiatan tersebut tentunya semakin banyak pula permasalahan yang muncul. Terutama di wilayah ruang angkasa yang mana membutuhkan teknologi tinggi untuk melakukan aktivitas di dalamnya Salah satunya adalah semakin banyaknya sampah ruang angkasa yang bertebaran di orbit bumi Melihat fakta seeperti ini, United Nation Convention On Peaceful Uses of Outer Space (UNCOPUOS), melalui salah satu badannya yang disebut Inter-Agency Space debris Coordination Committee (IADC) tidak menutup mata. Mereka telah menerbitkan sebuah panduan tentang hal-hal yang mungkin dilakukan oleh negara peluncur untuk mengurangi jumlah sampah ruang angkasa yang mungkin muncul di kemudian hari. Namun panduan tersebut berisi halhal yang sebaiknya dilakukan sebelum adanya peluncuran, tindakan-tindakan yang sifatnya preventif atau pencegahan. Selain sifatnya untuk pencegahan, isi dari buku panduan ini sifatnya adalah teknis. Lebih kepada panduan praktis yang sebaiknya dilakukan negara untuk mengurangi keberadaan sampah angkasa sedini mungkin. Tentunya instrumen hukum yang menjamin kepastian juga diperlukan, supaya semua pihak menaatinya. Permasalahannya adalah keberadaan sampah ruang angkasa ini telah cukup banyak jumlahnya. Diperlukan mekanisme kontrol terhadap permasalahan yang telah terjadi Setelah melihat pada rumusan permasalahan pertama di mana negara belum dapat memenuhi kewajiban atas outer space treaty, maka kiranya perlu dibuat perjanjian yang sifatnya lebih khusus lagi Selain outer space treaty sebagai perjanjian induk ada beberapa perjanjian lain yang mengikuti Perjanjian tersebut antara lain:

a. Agreement on the Rescue of Astronauts, the Return of Astronauts and the Return of Objects Launched into Outer Space. Perjanjian ini mengatur tentang prosedur pemberian bantuan kepada astronot atau objek dari benda angkasa yang mengalami kerusakan atau keadaan genting lainnya Convention on International Liability for Damage Caused by Space Objects. Konvensi ini mengatur bentuk tanggung jawab yang ditanggung oleh negara peluncur apabila kegiatannya mengakibatkan kerugian bagi negara atau pihak yang lain

b. Convention on Registration of Objects Launched into Outer Space

c. Konvensi ini mengatur caracara pendaftaran benda angkasa supaya menjadi jelas kepemilikin dari benda angkasa tersebut

d. Agreement Governing the Activities of States on the Moon and Other Celestial Bodies 
Perjanjian ini mengatur tentang kegiatan negara di bulan dan benda langit yang ada di ruang angkasa. Hal ini dimaksudkan untuk memperjelas dan mempertegas isi dari outer space treaty itu sendiri. Maka dari itu pembuatan perjanjian yang khusus mengatur tentang lingkungan yang mendukung kegiatan di ruang angkasa perlu untuk dibuat. Supaya semakin jelas pula kelangsungan untuk kegiatan di ruang angkasa pada masa yang akan dating. Terjadinya beberapa permasalahan tentang tertabraknya satelit yang masih aktif oleh space debris seharusnya sudah cukup menjadi acuan badan ruang angkasa yang ada di Perserikatan Bangsa-Bangsa supaya ada ketegasan hukum.

\section{Penutup \\ Simpulan}

Negara mengemban tanggung jawab secara internasional untuk mematuhi seluruh isi perjanjian dalam berkegiatan di ruang angkasa. Ini merupakan salah satu prinsip yang harus dipenuhi oleh Negara. Dalam hal ini, negara belum bisa memenuhi kewajibannya karena dianggap lalai dalam menjaga lingkungan ruang angkasa dari potensi bahaya yang mungkin dihasilkan oleh sampah ruang angkasa. Ini berarti negara belum bisa melaksanakan prinsipprinsip kegiatan di ruang angkasa seperti yang diinginkan outer space treaty. Dengan dibentuknya perjanjian khusus yang mengatur tentang pengontrolan sampah di ruang angkasa diharapkan setiap negara yang berkegiatan dapat lebih bertanggung jawab atas kegiatannya tersebut. Sehingga negara bukan hanya menggunakan ruang angkasa dengan sebebas-bebasnya tanpa memikirkan akibatnya Perlu juga dibuat sebuah aturan kerjasama antar semua pihak yang melakukan kegiatan di ruang angkasa sehingga terjadi suatu hubungan saling membantu antar mereka Terutama bagi negara-negara maju yang memiliki teknologi tinggi di ruang angkasa juga harus memberikan bantuan-bantuan dengan sebaikbaiknya apabila ada suatu permasalahan Hal ini semakin meningkatkan prinsip kerjasama negara di ruang angkasa Tiga hal yang menjadi dasar tersebut tentunya dapat menjadi alasan untuk segera dibentuk suatu pengaturan yang mengontrol keberadaan sampah ruang angkasa. Dapat ditarik kesimpulan bahwa prinsip tanggung jawab atas dasar kesalahan dapat berlaku bagi negara penuntut; negara yang juga ikut serta dalam memanfaatkan ruang angkasa, atau dengan kata lain negara penuntut merupakan negara peluncur yang meluncurkan benda angkasanya, dan benda angkasanya mengalami kerusakan akibat benda angkasa milik negara lain, serta kerusakan tersebut terjadi tidak di permukaan bumi.

\section{Saran}

Diharapkan dengan adanya instrumen hukum berupa perjanjian internasional maka negara yang melakukan aktivitas dapat menjalankan kewajibannya di ruang angkasa serta di lain sisi memberikan perlindungan hukum yang jelas kepada semua negara Sebagai dasar pembuatan perjanjian internasional terdapat tiga unsur yang harus dipenuhi. Ketiga unsur tersebut antara lain unsur filosofis, yang menjadi 
dasar dibentuknya suatu perjanjian. Unsur yuridis yang berisi tentang dasar hukum yang digunakan untuk membuat perjanjian serta unsur politis yang menjadi tujuan dari pembuatan perjanjian internasional. Semakin berkembang dan banyaknya kegiatan negara di ruang angkasa membuat kepadatan benda angkasa di orbit meningkat pesat. Sementara itu kegiatan negara di ruang angkasa tentunya akan terus berkembang dari masa ke masa. Untuk mengontrol hasil dari kegiatan negara di ruang angkasa inilah diperlukan peraturan yang sifatnya lebih pasti. Adanya peraturan yang pasti, membuat setiap negara yang berkegiatan di ruang angkasa akan lebih berhati-hati dan memikirkan kelangsungan dari lingkungan ruang angkasa. Maka dari itu ruang angkasa dapat menjadi tempat yang aman dan nyaman bagi semua negara yang ingin melakukan kegiatan di ruang angkasa sehingga generasi selanjutnya tetap dapat memanfaatkan ruang angkasa dengan sebaik-baiknya. Ini menjadi landasan filosofis atas perjanjian yang akan dibentuk.

\section{Daftar Pustaka}

Abdurrasyid, Priyatna, 1986, Hukum Antariksa Nasional (penempatan Urgensinya), Rajawali, Jakarta

Anonim "Berapa Jumlah Satelit Yang Mengorbit Bumi", http://www amazine co/14488/berapa-jumlahsatelityang-mengorbit-bumi/ Diakses 28 Maret 2015

Arifin, Seru, 2014, Hukum Perbatasan Darat Antar Negara, Sinar Grafika, Jakarta
Priyatna Abdurrasyid, Pengantar Hukum Ruang Angkasa Dan Space Treaty 1967, Binacipta, Bandung, 1977.

Priyatna Abdurrasyid, Hukum Antariksa Nasional, Rajawali Pers, Jakarta, 1989.

Verschoor, Diederiks Beberapa Persamaan dan Perbedaan Antara Hukum Udara dan Hukum Ruang Angkasa Terjemahan oleh Bambang Iriana Jakarta: Sinar Grafika, 1991.

Wirapradja, E Saefullah Pengantar Hukum Udara dan Ruang Angkasa Bandung: Alumni, 2014

Mangku, D. G. S. (2010). Pelanggaran terhadap Hak Kekebalan Diplomatik (Studi Kasus Penyadapan Kedutaan Besar Republik Indonesia (KBRI) di Yangon Myanmar berdasarkan Konvensi Wina 1961). Perspektif, 15(3).

Mangku, D. G. S. (2011). Peluang dan

Tantangan ASEAN Dalam Penyelesaian Sengketa Kuil Preah Vihear Di Perbatasan Kamboja dan Thailand. Pandecta: Research Law Journal, 6(2).

Mangku, D. G. S. (2012). Suatu Kajian Umum tentang Penyelesaian Sengketa Internasional Termasuk di Dalam Tubuh ASEAN. Perspektif, 17(3).

Mangku, D. G. S. (2013). Kasus Pelanggaran Ham Etnis Rohingya: Dalam Perspektif ASEAN. Media Komunikasi FIS, 12(2).

Mangku, D. G. S., \& Itasari, E. R. (2015). Travel Warning in 
Jurnal Media Komunikasi Pendidikan Pancasila dan Kewarganegaraan

Volume 2, Nomor 1 April 2020

International Law

Perspective. International

Journal of Business, Economics and Law, 6(4).

Periani, A., \& Mangku, D. G. S. Implementation Of Asean Convention On Counter Terrorism In Eradication Of Terrorism That Happens In The South Asia Area.

Purwanto, H., \& Mangku, D. G. (2016). Legal Instrument of the Republic of Indonesia on Border Management Using the Perspective of Archipelagic State. International Journal of Business, Economics and Law, 11(4).

Purwendah, E., Mangku, D., \& Periani, A. (2019, May). Dispute Settlements of Oil Spills in the Sea Towards Sea Environment Pollution. In First International Conference on Progressive Civil Society (ICONPROCS 2019). Atlantis Press.

Mangku, D. G. S. (2018). Kepemilikan Wilayah Enclave Oecussi Berdasarkan Prinsip Uti Possidetis Juris. Jurnal Advokasi, 8(2), 150-164.

Mangku, D. G. S. (2017). The Efforts of Republica Democratica de Timor-Leste (Timor Leste) to be a member of Association of Southeast Asian Nations (ASEAN) and take an active role in maintaining and creating the stability of security in Southeast Asia. Southeast Asia Journal of Contemporary Business, Economics and Law, 13(4), 18-24.

Mangku, D. G. S., \& Radiasta, I. K. (2019). Tanggung Jawab
Negara terhadap Penembakan

Pesawat MH17 berdasarkan Hukum

Internasional. Pandecta: Research Law Journal, 14(1), 25-33.

Yuliartini, N. P. R., \& Mangku, D. G. S. (2019). Tindakan Genosida terhadap Etnis Rohingya dalam Perspektif Hukum Pidana Internasional. Majalah Ilmiah Cakrawala Hukum, 21(1), 4149.

Widayanti, I. G. A. S., Mangku, D. G. S., SH, L. M., Yuliartini, N. P. R., \& SH, M. (2019). Penggunaan Tentara Anak Dalam Konflik Bersenjata Ditinjau Dari Perspektif Hukum Humaniter (Studi Kasus: Konflik Bersenjata Di Sri Lanka). Jurnal Komunitas Yustisia, 2(1).

Anggreni, I. A. K. N., Mangku, D. G. S., SH, L. M., Yuliartini, N. P. R., \& SH, M. (2019). Analisis Yuridis Pertanggungjawaban Pemimpin Negara Terkait Dengan Kejahatan Perang Dan Upaya Mengadili Oleh Mahkamah Pidana Internasional (Studi Kasus Omar Al-Bashir Presiden Sudan). Jurnal Komunitas Yustisia, 2(1).

Itasari, E. R., \& Mangku, D. G. S. Fulfillment Of Educational Rights For Indonesian Citizens Who Are In The Border Areas With Neighborhoods.

SETIAWATI, N., Mangku, D. G. S., SH, L. M., Yuliartini, N. P. R., \& SH, M. (2019). Penyelesaian Sengketa Kepulauan Dalam Perspektif Hukum Internasional (Studi Kasus Sengketa 
Jurnal Media Komunikasi Pendidikan Pancasila dan Kewarganegaraan

Volume 2, Nomor 1 April 2020

Perebutan Pulau Dokdo antara Jepang-Korea Selatan). Jurnal Komunitas Yustisia, 2(1).

Mangku, D. G. S., Triatmodjo, M., \& Purwanto, (2018). Pengelolaan Perbatasan Darat Antara Indonesia Dan Timor Leste Di Wilayah Enclave Oecussi (Doctoral dissertation, Universitas Gadjah Mada).

Purwanto, H., \& Mangku, D. G. S. Border Security In Indonesia And Papua New Guinea.
Mangku, D. G. S. Indonesian Government Authority In Terms Of Border Management With Other Countries.

Mangku, D. G. S. (2018). Legal Implementation On Land Border Management Between Indonesia And Papua New Guinea According to Stephen B. Jones Theory. Veteran Law Review, 1(1), 72-86. 